\title{
Modeling cross-scale relationships between climate, hydrology, and individual animals: generating scenarios for stream salamanders
}

OPEN ACCESS

Edited by:

Marco Casazza,

'Parthenope' University of Naples, Italy

Reviewed by:

Ke-Seng Cheng,

National Taiwan University, Taiwan Jagdish Krishnaswamy,

Ashoka Trust for Research in Ecology and the Environment, India

*Correspondence: Lael Parrott,

Okanagan Institute for Biodiversity, Resilience, and Ecosystem Services, The University of British Columbia, Okanagan Campus, Science building,

1177 Research Road, Kelowna, BC V1V 1V7, Canada lael.parrott@ubc.ca

Specialty section: This article was submitted to

Environmental Informatics,

a section of the journal

Frontiers in Environmental Science

Received: 16 March 2015 Accepted: 03 July 2015

Published: 21 July 2015

Citation:

Girard P, Levison J, Parrott L, Larocque M, Ouellet M-A and Green DM (2015) Modeling cross-scale relationships between climate, hydrology, and individual animals: generating scenarios for stream salamanders.

Front. Environ. Sci. 3:51. doi: 10.3389/fenvs.2015.00051
Philippe Girard ${ }^{1}$, Jana Levison ${ }^{2}$, Lael Parrott ${ }^{3 *}$, Marie Larocque ${ }^{4}$, Marie-Audray Ouellet ${ }^{4}$ and David M. Green ${ }^{5}$

\begin{abstract}
'Département de Géographie, Université de Montréal, Montreal, QC, Canada, ${ }^{2}$ School of Engineering, University of Guelph, Guelph, ON, Canada, ${ }^{3}$ Okanagan Institute for Biodiversity, Resilience, and Ecosystem Services, The University of British Columbia, Kelowna, BC, Canada, ${ }^{4}$ Département des Sciences de la Terre et de l'Atmosphère, Centre de Recherche Pour l'Étude et la Simulation du Climat à l'Échelle Régionale, Université du Québec à Montréal, Montréal, QC, Canada, ${ }^{5}$ Redpath Museum, McGill University, Montreal, QC, Canada
\end{abstract}

Hybrid modeling provides a unique opportunity to study cross-scale relationships in environmental systems by linking together models of global, regional, landscape, and local-scale processes, yet the approach is rarely applied to address conservation and management questions. Here, we demonstrate how a hybrid modeling approach can be used to assess the effect of cross-scale interactions on the survival of the Allegheny Mountain Dusky Salamander (Desmognathus ochrophaeus) in response to changes in temperature and water availability induced by climate change at the northern limits of its distribution. To do so, we combine regional climate modeling with a landscape-scale integrated surface-groundwater flow model and an individual-based model of stream salamanders. On average, climate scenarios depict a warmer and wetter environment for the 2050 horizon. The increase in average annual temperature and extended hydrological activity time series in the future, combined with a better synchronization with the salamanders' reproduction period, result in a significant increase in the long-term population viability of the salamanders. This indicates that climate change may not necessarily limit the survivability of small, stream-dwelling animals in headwater basins located in cold and humid regions. This new knowledge suggests that habitat conservation initiatives for amphibians with large latitudinal distributions in Eastern North America should be prioritized at the northern limits of their ranges to facilitate species migration and persistence in the face of climate change. This example demonstrates how hybrid models can serve as powerful tools for informing management and conservation decisions.

Keywords: hybrid ecological modeling, climate change, habitat conservation, hydrological modeling, individual-based modeling, stream salamanders 


\section{Introduction}

While the body of literature about the impacts of climate change on a variety of species at global or regional scales is growing (Enquist, 2002; Midgley et al., 2002; Thomas et al., 2004; Malcolm et al., 2006), few studies have attempted to predict the fate of local ecosystems facing global warming. This is a major shortcoming as most conservation and management strategies are implemented locally. There are many reasons why the local scale has been mostly ignored, but one essential factor is the difficulty of relating broad scale climate change impacts to natural mechanisms affecting individuals at a given place and time (Wilbanks and Kates, 1999; Russell et al., 2009). Climate change involves complex, cross-scale effects acting concurrently upon numerous dynamic processes, both biological and environmental (Hulme, 2005). Predicting the impacts of such complex interactions is challenging, especially when data are lacking and knowledge gaps add uncertainty to climate predictions.

The potential impacts of climate change on amphibian populations provide a telling example of complex, cross-scale effects. Amphibians are believed to be highly vulnerable to global environmental change (Blaustein et al., 2001; Wake and Vredenburg, 2008) and major population declines have been documented worldwide over the past 30 years (Pounds et al., 1997; Green, 2003; D’Amen and Bombi, 2009). Amphibians are poikilotherms, which means that ambient temperature has a significant influence on these species' physiological, metabolic, and life-history traits (Carey and Alexander, 2003). In addition to these direct temperature effects, the potential of climate change to impact available water (Oki and Kanae, 2006) may also be expected to affect their habitat. Generally dependent upon moisture to varying degrees (Petranka, 1998), amphibians can be extremely vulnerable to changes in, for example, surface runoff, stream flow, groundwater levels, and associated spring activity (Alvo et al., 2003). In headwater basins associated with nearsurface fractured bedrock aquifers, groundwater is likely to be vulnerable to climate change due to steep slopes, thin soil cover, and low permeability favoring runoff at the expense of infiltration (Kosugi et al., 2006). Climate change impacts on groundwater resources at a regional scale are increasingly studied (Jyrkama and Sykes, 2007; Scibek et al., 2007), but the magnitude of these changes is highly uncertain (Green et al., 2011). In particular, headwater basins have been the focus of only limited research (Levison et al., 2014a) and the impacts of climate change on habitat suitability for spring-restricted animals, such as many salamanders, remain largely unknown. However, depending on the extent and timing of the changes with respect to the species' life cycle, the impact could be very different from one part of the species' geographic range to another.

Given the uncertainty about the magnitude and timing of changing hydrological events, and their potential impacts on stream-dwelling amphibians, it is unclear how these species may be affected by climate change in the northern limits of their distributions. Although the increased temperatures may be beneficial, changes in the timing of the spring freshet or severity of summer droughts could have potentially devastating effects on these animals. In this work, climate models, a groundwater flow model and an individual-based model of salamander distribution and abundance are combined to develop a succession of models linking physical and ecological processes across global, regional and local spatial scales, with the aim of predicting the fate of the Allegheny Mountain Dusky Salamander (Desmognathus ochrophaeus) in the Covey Hill Natural Laboratory (Larocque et al., 2006) of southern Quebec. This approach, by integrating the linkages between regional-scale climate change, local hydrology, and salamander life cycles, may yield realistic predictions concerning the long-term survival of salamander populations, and estimates of associated uncertainty, for use in planning conservation strategies.

\section{Materials and Methods}

\section{Species and Sampling Site}

The Allegheny Mountain Dusky Salamander, D. ochrophaeus (Family Plethodontidae), inhabits seepage areas, small intermittent streams, and groundwater-fed springs (Sharbel and Bonin, 1992; Lannoo, 2005). The species is highly dependent on water availability for survival, reproduction and dispersal. The species can live for 4-5 years, going through a life cycle that involves a series of stages, including egg, larval, juvenile, and adult phases. Eggs are usually laid in spring in wet crevices, under logs, on moss in seepage areas or near small streams, and usually hatch in late summer. The resulting larvae must develop in water and typically metamorphose the following spring (Petranka, 1998). Adults and juveniles may disperse into adjacent wooded areas in wet weather and are often abundant on wet rock faces (Petranka, 1998). Though listed by the IUCN as "Least Concern" (Hammerson, 2004), the species' status at the northern edge of its distribution is precarious. In Canada, known occurrences are restricted to two locations: the Niagara Escarpment in southern Ontario and Covey Hill in southern Quebec. Both populations are listed as endangered federally and provincially (COSEWIC, 2009). For stream salamanders, temperature and moisture are the primary resources that limit their distribution, as well as the ability of eggs and larvae to survive, and for this reason these two variables have been chosen as the focus of this modeling study.

The Covey Hill Natural Laboratory (Larocque et al., 2006) is located immediately north of the Canada-USA border, in the northernmost extension of the Adirondack Mountains (Figure 1). The hill is composed of Potsdam Group sandstones, deformed and fractured during the Appalachian orogeny (Globensky, 1986). The absence of surface deposits over large areas near the top of the hill shows the extent of erosion during the last glaciation (12 Ma). The sandstone aquifer is generally unconfined over much of the study area. Groundwater flows mainly through fractures in the sandstone (Nastev et al., 2008). Where these fractures intersect the ground surface, groundwater discharge in the form of springs may be found, creating habitats well-suited for stream-dwelling salamanders. The landscape surrounding Covey Hill is a peri-urban agricultural region and is thus largely inhospitable to the Mountain Dusky Salamander. Maintaining appropriate habitat for the species on Covey Hill is therefore crucial to its survival in Southern Quebec. 


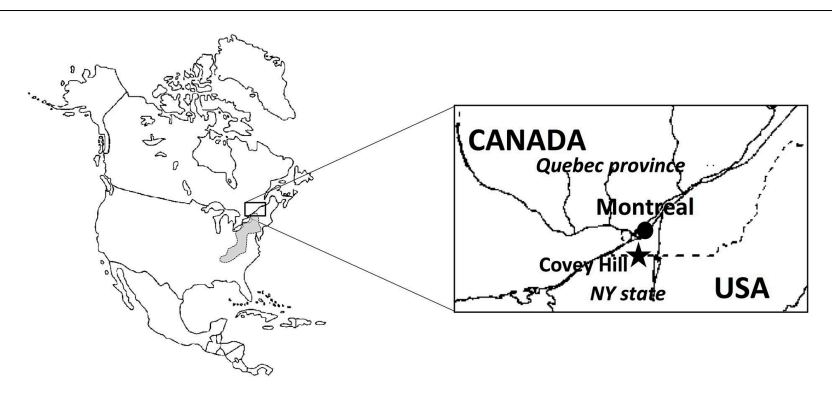

FIGURE 1 | Location of the study site in the Covey Hill area. The hill is on the northern edge of the putative distribution of the Allegheny Mountain Dusky Salamander (shaded zone).

Covey Hill is an important recharge area for the Châteauguay River regional aquifer (Croteau et al., 2010), which extends over $2500 \mathrm{~km}^{2}$. The monthly average temperature observed between 1971 and 2000 in the Covey Hill area ranges between $-9.6^{\circ} \mathrm{C}$ in January and $20.6^{\circ} \mathrm{C}$ in July with minima down to $-30.5^{\circ} \mathrm{C}$ in winter and maxima up to $30.3^{\circ} \mathrm{C}$ in summer. The average annual temperature is $6.4^{\circ} \mathrm{C}$. Precipitation is relatively evenly distributed throughout the year, ranging between 40.6 and $93.3 \mathrm{~mm}$ in February and July, respectively. The average monthly precipitation is $72 \mathrm{~mm}$ for a total annual average of $872.4 \mathrm{~mm}$. Weather data are based on Environment Canada measurements at the Hemmingford, QC weather station.

\section{Modeling Approach}

Over the last decade, spatially-explicit individual-based models linked to landscape-scale process models have emerged as powerful tools in conservation, management, and planning (Grimm and Railsback, 2005; Stillman and Goss-Custard, 2010; McClain et al., 2012; Metcalfe et al., 2012; Parrott et al., 2012). By considering individual variations, entire life cycles, interactions among individuals and interactions between individuals and their immediate environment, this approach allows for accurate predictions about local viability of species in response to land use change or modification of landscape-scale environmental processes. The approach was used here to predict the fate of Mountain Dusky salamanders on Covey Hill in response to changes in temperature and water availability induced by climate change.

Three types of models operating at various spatial and temporal resolutions were combined (Figure 2). First, daily temperature and precipitation scenarios were obtained from an ensemble of regional climate models. Second, these outputs were input into an integrated surface-groundwater flow model to simulate the impact of these climate changes on groundwaterfed spring activity. Third, simulated daily time series of spring activity based on flow output from the groundwater model and daily temperature time series from the climate models were used as input data for an individual-based population model built specifically for stream-dwelling salamanders (Girard et al., 2015).

\section{Climate Scenarios}

The climate change scenarios are derived from three Regional Climate Models (RCMs) driven by five General Circulation
Models (GCMs). This form of dynamic downscaling provides a better representation of both average conditions and extremes than other methods over the study area. Future RCM scenarios were further downscaled to a spatial resolution of $45 \mathrm{~km}$ and a temporal resolution of $24 \mathrm{~h}$ using the daily translation bias correction method (Mpelasoka and Chiew, 2009) to remove the biases between simulated and observed temperature and precipitation variables.

Although the ability of climate models to reproduce observed climate conditions during a reference period does not automatically guarantee more reliable results for future projections (Chiew et al., 2009; Gosling et al., 2011; Ledbetter et al., 2011) model performance remains nevertheless an important aspect to verify before any interpretation of climate simulations. Discrepancies found between observed and simulated climate variables for the reference period can be used to remove the consequent bias from future climate simulations to obtain simulations that are more in line with reality (cf. Samuel et al., 2012). In this study, bias correction was performed on RCM climate datasets (daily temperature and daily precipitation) following Mpelasoka and Chiew (2009). This method has proven effective not only in reproducing mean changes of temperature and precipitation, but in reproducing the full distribution of these variables, i.e., changes in extremes.

The modeled data were compared with weather data recorded at Hemmingford Four Winds meteorological station (Climate ID: 7023075) for a reference period of 1970-2000. The mean absolute deviation for observed average monthly temperature and modeled average monthly temperature over the 30 year reference period is $0.4^{\circ} \mathrm{C}\left(0.2^{\circ} \mathrm{C}\right.$ in January and $0.2^{\circ} \mathrm{C}$ in July, with slightly higher deviations for the months of February is $1.4^{\circ} \mathrm{C}$ and September is $0.6^{\circ} \mathrm{C}$ ). The mean absolute deviation for observed average monthly rainfall and modeled average monthly rainfall over the same 30 -year period amounts to $4.6 \mathrm{~mm}$ or $5.5 \%$ ( $5.5 \mathrm{~mm}$ or $10.7 \%$ in January and $1.1 \mathrm{~mm}$ or $1.2 \%$ in July). Keeping in mind that the comparison of modeled values with corresponding values estimated from available station data must take into consideration the fact that the spatial scales related to these estimates are different (areal vs. point estimates), these values are within the acceptable margin of error which can be found in the literature (Moberg and Jones, 2004; Mailhot et al., 2007; Turco et al., 2013).

Nine climate projections were selected from the 25 dynamically downscaled simulations available for the Covey Hill area (see Table 1). Most of the simulations are outputs of the Canadian Regional Climate Model (CRCM) (Music and Caya, 2007) and were generated and supplied by the Ouranos Consortium on Regional Climatology and Adaptation to Climate Change. The remaining simulations are from the North American Regional Climate Change Assessment Program (NARCCAP). All projections are for the 2041-2070 climate. The nine simulations account for $85 \%$ of the future climate variability projected for the study site as established by a cluster analysis carried out on the range of available RCM scenarios. The simulations include Intergovernmental Panel on Climate Change emissions scenarios A1B and A2 (IPCC, 2000). 


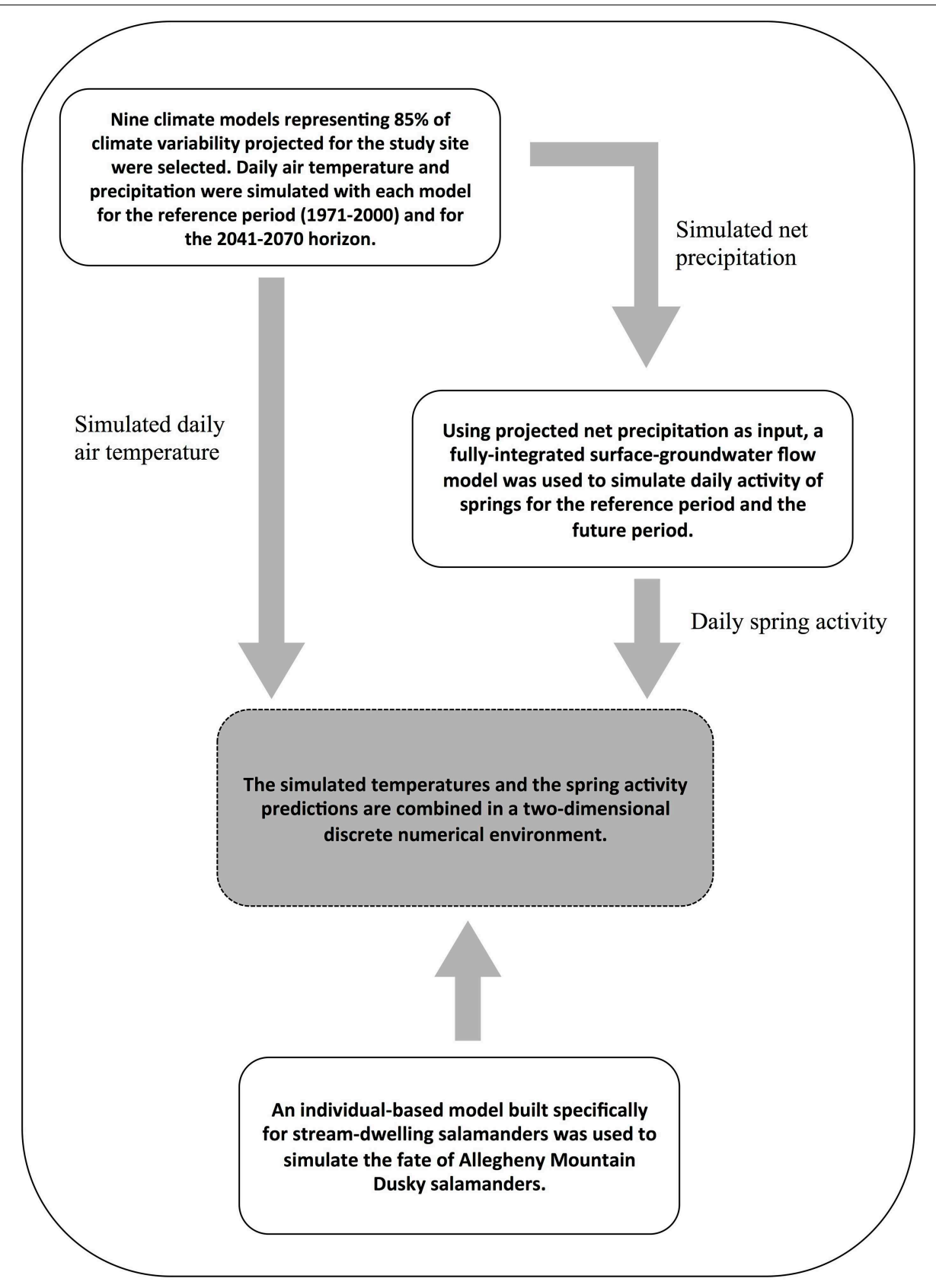

FIGURE 2 | Overview of the methodology used to predict the viability of stream salamanders in a changing climate.

Altogether, climate scenarios depict a warmer and wetter environment for the 2050 horizon (Table 1). The climate model ensemble predicts an increase in annual temperature ranging from 2 to $3.5^{\circ} \mathrm{C}$ over the $2041-2070$ period, compared to the 1971-2000 reference period. An increase between 3 and 17\% in annual precipitation is expected during the same period. This increase varies depending on the month of the year, although variability remains relatively equal throughout the year. Consensus among models over precipitation change is however less apparent. On average, models forecast an increase in precipitation for all months except in June. Although most models predict an increase in precipitation during the winter, the range of values is wide (from -3 to $+47 \%$ ). Conversely, no real consensus can be observed during the summer and autumn, where precipitation changes vary from -19 to $+33 \%$. More details on the climate scenarios can be found in Levison et al. (2014a).

Following Oudin et al. (2005), the increased temperatures predicted by the climate scenarios induce a 15 to $21 \%$ increase in predicted potential evapotranspiration as compared to the reference period. Stemming from these changes, net precipitation (i.e., precipitation-potential evapotranspiration) 
TABLE 1 | Details for the nine climate projections selected for this study out of the group of 25 available for the region: emission scenario, simulated air temperature and precipitation changes, and derived potential evapotranspiration changes (derived from Levison et al., 2014b).

\begin{tabular}{|c|c|c|c|c|c|c|c|c|}
\hline & $\mathrm{RCM}$ & GCM & Run & Domain & $\begin{array}{l}\text { Emission } \\
\text { scenario }\end{array}$ & $\begin{array}{c}\text { Air temperature } \\
\text { change }\left({ }^{\circ} \mathrm{C}\right)\end{array}$ & $\begin{array}{l}\text { Precipitation } \\
\text { (\% change) }\end{array}$ & $\begin{array}{c}\text { Net precipitation } \\
\text { (\% change) }\end{array}$ \\
\hline 1 & CRCM4.2.3 & CGCM3 & 5 & AMNO & A2 & 3.1 & 8 & 13 \\
\hline 2 & CRCM4.2.3 & CGCM3 & 2 & AMNO & A2 & 3.2 & 9 & 12 \\
\hline 3 & CRCM4.2.3 & ECHAM5 & 1 & AMNO & A2 & 2.2 & 12 & 15 \\
\hline 4 & CRCM4.2.3 & ECHAM5 & 2 & AMNO & $\mathrm{A} 2$ & 2.5 & 10 & 6 \\
\hline 5 & CRCM4.2.3 & Arpège UnifS2 & - & AMNO & $\mathrm{A} 1 \mathrm{~B}$ & 1.9 & 7 & 8 \\
\hline 6 & CRCM4.2.0 & CGCM3 & 4 & AMNO & A2 & 2.8 & 6 & 5 \\
\hline 7 & CRCM & CCSM & - & N. Amer. & $\mathrm{A} 2$ & 3 & 2 & -4 \\
\hline 8 & ECP2 & GFDL & - & N. Amer. & A2 & 2.6 & 12 & 11 \\
\hline 9 & RCM3 & CGCM3 & - & N. Amer. & A2 & 2.7 & 3 & 0 \\
\hline
\end{tabular}

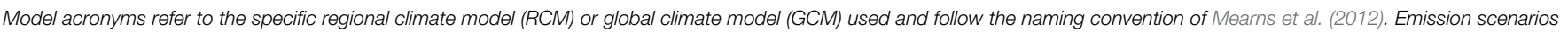
$A 2$ and $A 1 B$ are defined by the Intergovernmental Panel on Climate Change (IPCC).

varies from a $4 \%$ decrease (CRCM_CCSM) to a $15 \%$ increase (CRCM4.2.3_ECHAM\#1). The majority of net precipitation scenarios agree on the sign of change: seven out of nine predict an increase in mean net precipitation.

\section{Hydrogeological Model}

The daily flow of groundwater through bedrock fractures to springs on the northeastern face of Covey Hill was simulated by Levison et al. (2014b) using HydroGeoSphere software (HGS; Therrien et al., 2012). The numerical integrated surfacegroundwater flow model simulated four springs at elevations of $140,150,162$, and $177 \mathrm{~m}$. Levison et al. (2014b) have shown that for the 1971-2000 reference period, the lower elevation spring $(140 \mathrm{~m}$ ) is the one that flows most often during the year (on average 282 days, more than $75 \%$ of the year) (Figure 3). Spring activity decreases sharply at $150 \mathrm{~m}$ and at $162 \mathrm{~m}$ and increases slightly at the highest spring located at $177 \mathrm{~m}$. The greater activity at the lowest spring is explained by its position near the base of the hill. Flow period decreases for the 150 and $162 \mathrm{~m}$ elevations because of reduced water pressure from above as elevation increases. The greater spring activity period at the highest spring occurs because this spring is located at the intersection of an important sub-horizontal fracture and the ground surface, as opposed to the two middle-elevation springs which discharge from vertical fractures. Applying the net precipitation for the climate change scenarios (2041-2070) to the model, Levison et al. (2014b) has shown that increases in precipitation predicted by the climate scenarios during the 2041-2070 period has direct consequences on groundwater recharge, and thus on the spring activity time series. In the future, an increase in the length of spring activity periods is expected at all elevations. Spring activity increases on average by 7 days per year at $140 \mathrm{~m}, 9$ days at $150 \mathrm{~m}$, 6 days at $162 \mathrm{~m}$, and 5 days at $177 \mathrm{~m}$. This increase is statistically significant for all four spring elevations.

For each spring, the number of days when the spring is active, the mean length of activity periods, the seasonal partitioning of spring activity and the magnitude of flow were calculated for both the reference (1970-2000) and the future (2041-2070) periods. Binary spring activity time series were built according to whether the spring was active or inactive. Only the binary spring activity time series were used in the salamander model. Results from these simulations were used to calibrate the salamander model (see below).

\section{Salamander Model}

The individual-based model developed in this work has been previously described in Girard et al. (2015). The model simulates the life cycle (growth and development) and movement of individual salamanders at a daily time step in response to environmental variables (temperature and humidity). The biological functions implemented in the model are restricted to growth, life cycle stage transition, dispersal, reproduction, and mortality. Growth and life cycle stage transition functions are temperature dependent functions. Reproduction requires water during the reproductive period in order to occur, and eggs and larvae require water to survive. Similarly, adult salamanders will die if they cannot find water after an extended period of time. Dispersal is oriented toward humid areas and is density dependent for juveniles. The salamander model has been validated and calibrated based on field data for the Allegheny Mountain Dusky Salamander and provides reasonably accurate life cycle and distribution patterns in response to spatiotemporal temperature and humidity data for the environment (Girard et al., 2015).

In the model, the individual salamanders live and move about in a spatial environment consisting of a two-dimensional landscape describing water features and a daily air temperature profile that is uniform across the landscape. The effects of precipitation are implicitly taken into account through their effects on the spring activity time series, which affects the presence or absence of water features on the landscape. All other habitat-related aspects such as the availability of resources, shelter or the presence of predators are ignored. The landscape is represented by a grid with a resolution of $1 \mathrm{~m}^{2}$. Each grid cell may have one of three states: dry, humid or wet, with wet cells being those located directly in streams or springs. The cells at the edges of the grid are in a fourth state (exit cell) that allows individuals to leave the numerical landscape (permanently). Thus, the 

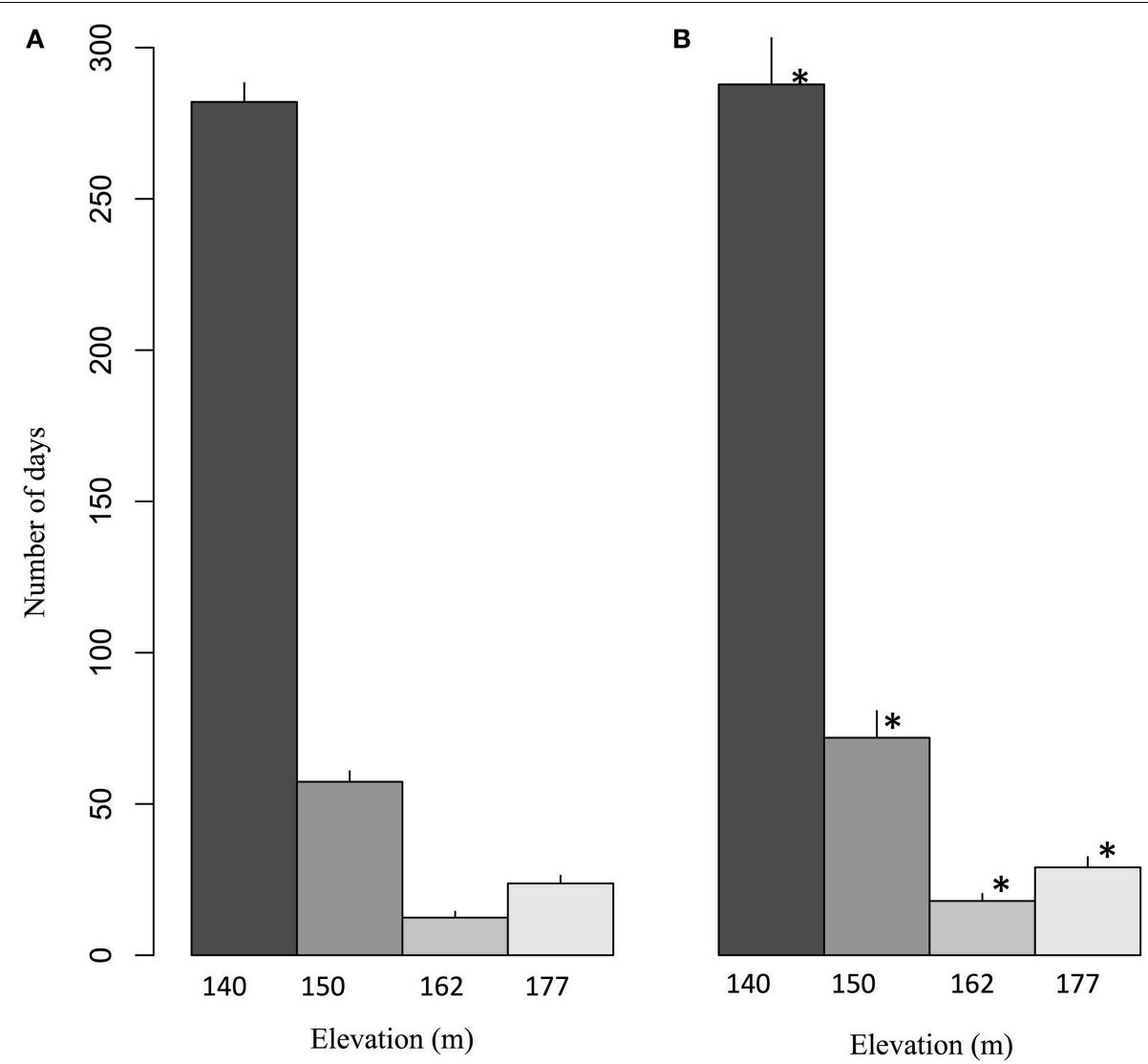

FIGURE 3 | Average number of days per year for which springs at different elevations are expected to flow during (A) the 1971-2000 reference period and (B) the 2041-2070 future period. The values correspond to ensemble averages and

numerical environment allows emigration, but immigration from the exterior does not occur. While the environment is represented as a discrete grid, salamanders move, and disperse in a continuous space.

The locations of the intermittent streams and groundwater springs on Covey Hill are coarsely known at best, and the density of the Allegheny Mountain Dusky Salamander population is unknown in most parts of the site. To overcome these limitations, the Covey Hill environment was represented by a simplified landscape that reproduces the expected temperature conditions and hydrodynamics predicted by the climate models and HGS model for generic springs on the hill. The simulated landscape thus represents a square-shaped spring of 1,4 , or $9 \mathrm{~m}^{2}$ located in the center of a $50 \times 50 \mathrm{~m}$ grid. This spring alternates between two states, active or inactive, following the activity time series derived from the hydrological simulations at elevations of 140, 150,162 , or $177 \mathrm{~m}$ on Covey Hill (Figure 4A). When the spring is active, its surface is composed of wet cells surrounded by $2 \mathrm{~m}$ of humid cells. The rest of the grid is composed of dry cells (Figure 4B). When the spring is inactive, its surface is composed of humid cells and the remainder of the grid is composed of dry cells (Figure 4C). Daily temperature time series are derived from the climate scenarios (Figure 4D). For error bars represent the standard deviation. The stars correspond to significant differences $(\alpha=0.05)$ according to a Wilcoxon-Mann-Whitney test for paired samples (Adapted from Levison et al., 2014b).

each of these models, the reference period (1971-2000) is compared to the future period (2041-2070). In total, 108 pairs of numerical environments (three areas $x$ four elevations $\times$ nine climate models) were tested. Although they might not be representative of specific locations on Covey Hill, these simplified environments nonetheless provide indications about the general fate of salamanders in typical habitats at different elevations of this hill and can be considered representative of similar regions in eastern North America. As described in Girard et al. (2015), the model's predictions of salamander life cycles and population densities were calibrated for the reference period using available environmental data for the region and known salamander densities estimated from field data.

\section{Challenges in Linking the Models Across Scales}

Linking models that operate at different temporal and spatial scales was one of the main challenges of this modeling study. The hydrogeological model, for example, predicted water table height over time at different elevations in our study area; this was more information than was required for the salamander model. The hydrological time series was thus simplified to retain only the necessary information, which is when the spring is active (i.e., the water table height permits spring flow) or not-active (i.e., the 


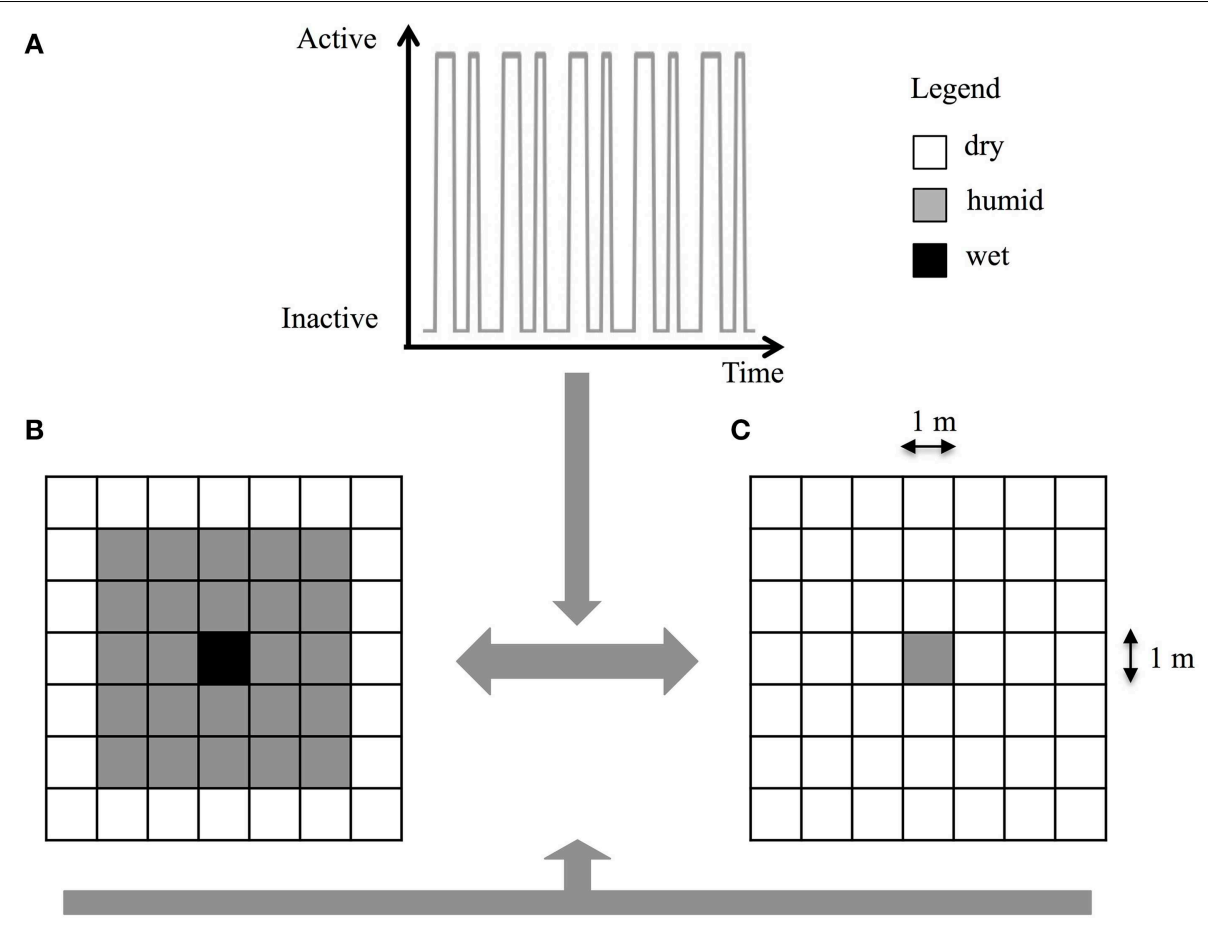

D

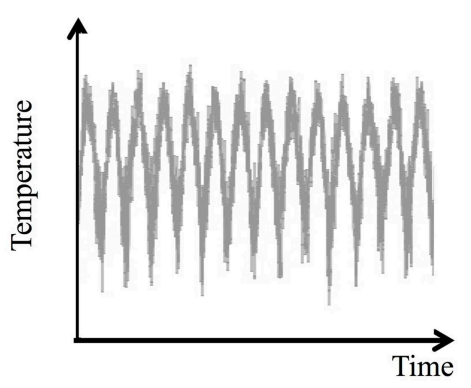

FIGURE 4 | Numerical environment of a single isolated spring located at the center of a $50 \times 50 \mathrm{~m}$ landscape (for display purposes, the size of the landscape in (B) and (C) was reduced to $7 \times 7 \mathrm{~m})$. (A) Activity time series derived from the groundwater flow model, (B) active spring cell, (C) inactive spring cell, and (D) temperature air profile. water table is too low for the spring to flow). The salamander and hydrological models were thus directly coupled, however the salamander model did not use all of the information output by the hydrological model. The salamander model thus did not directly use precipitation data from the regional climate model. It did use daily air temperature from the climate scenarios as a direct input for the 30-year reference period followed by the 30-year future period (2041-2070). Any uncertainty in predicted daily temperatures is thus translated into predictions of salamander viability and in particular the influence of temperature on the salamander life cycle.

Coupling the hydrogeological model to the climate data also posed challenges. The hydrogeological model requires the use of net precipitation (which is precipitation minus evapotranspiration) as an atmospheric water input. As noted in Levison et al. (2014b), the model directs net precipitation to surface flow (runoff) and infiltration (recharge). Predicted net precipitation and evapotranspiration values were derived from the regional climate scenarios described above. Although the modeled climate data satisfactorily matched historical climate records for the area, any uncertainty in predictions of the future climate have been transferred to the hydrological model and indirectly to the salamander model.

\section{Predicting Climate Change Impacts on Salamander Populations}

The impacts of climate change were assessed through a series of simulations using the calibrated salamander model implemented in the 108 pairs of numerical environments. Each simulation lasted 21,000 days. Simulations began on January 1st with 20 adults randomly distributed in the area of influence of the spring cells (wet and humid cells combined). The sex of these individuals was set randomly to ensure a balanced sex ratio. The first 10,950 days (corresponding to the 30-year reference period) were performed in springs showing constant activity to allow the model to reach a stable salamander population. 
Activity and temperature profiles predicted by the hydroclimatic simulations were then implemented on the 10,951st day and run for 30 years. For each of the 216 simulated environments, 10 replicate simulations were run. At the end of each simulation, the abundance of adults over the last 5000 days was calculated. The probability of extinction through the 10 repetitions of a given numerical environment was also evaluated.

\section{Results}

The increase in the spring activity time series is not homogeneous during the year. Values presented in Table 2 represent the interannual mean of the total number of flowing days for each spring per season. The number of flowing days during the winter increases at all four elevations, a potential indication for an earlier onset of spring freshet. In the spring season, the number of days of activity also generally increases while it decreases during the summer and fall. Activity changes for the future period are statistically significant during winter and spring seasons according to a Wilcoxon-Mann-Whitney test for paired samples ( $\alpha=0.05$ ), but are not significant during summer and fall. These results suggest an intensification of the hydrological activity in the Covey Hill springs for the 2050 horizon. This increased activity is likely due to a shorter winter period and to earlier spring snowmelt.

The simulations predict a strong elevation effect on the viability of salamander populations for the reference period. While stable population sizes were obtained at lower elevation springs (140 and $150 \mathrm{~m}$; Figure 5A), the springs located at 162 and $177 \mathrm{~m}$ were not able to sustain salamander populations, which went locally extinct with a probability close to 1 (Figure 5B). However, the increase in average annual temperature and extended hydrological activity time series in the future resulted in a significant improvement for salamander populations. This improvement occurred on two fronts. First, at elevations which could sustain salamander populations during the reference period ( 140 and $150 \mathrm{~m}$ ), an increase in population size of about $20 \%$ was predicted by the model (Figure 5A). Second, the increased hydrological activity at higher elevations $(162$ and $177 \mathrm{~m})$ resulted in a significant decrease in the probability of extinction (Figure 5B). Interestingly, the increased viability of the population both in terms of abundance and extinction probability is better at $162 \mathrm{~m}$ than at $177 \mathrm{~m}$ despite the fact that spring activity is generally lower at $162 \mathrm{~m}$. This result suggests that water availability is not the only factor influencing salamander population viability. Unlike the increase projected for the $162 \mathrm{~m}$ spring, no increase in hydrological activity is projected for the $177 \mathrm{~m}$ spring over the spring season (i.e., during an important part of the reproduction period). This observed difference in seasonal activity suggests that the timing of the increased spring activity exerts as great an influence as its magnitude on salamander viability.

The warmer future climate has a significant predicted impact on some critical eco-physiological traits of the salamanders such as life cycle duration and range of the reproduction period (Figure 6). Rising temperatures significantly accelerate the life cycle. According to the model, during the recent past, an average of 4.5 years separated oviposition from sexual maturation. This period was reduced by 5 months on average in the future due to the temperature increase (Figure 6A). Reproduction itself was also favored by the temperature increase since the oviposition season was extended by a dozen days on average, as a consequence of an earlier onset (Figure 6B).

In the salamander individual-based model, oviposition cannot be achieved if a female is not in water. Therefore, in an inactive spring, reproduction is prevented, even if ambient temperatures are adequate for reproduction. The overlap between the spring activity period and the reproduction season thus defines an effective reproduction period. During the reference period, springs were active for less than $2 \%$ of the breeding season (Figure 7A). However, the longer spring activity in the future, combined with a better synchronization with the reproduction period, increased this overlap to nearly $5 \%$ on average (Figure 7A). Simulations show that the number of years where spawning was not possible due to spring inactivity during the reproduction season decreased significantly during the future period at higher elevations (Figure 7B).

\section{Discussion}

The significant population improvements projected for the Allegheny Mountain Dusky Salamanders on Covey Hill for the 2050 horizon is an example demonstrating the intricate, crossscale effects of global climate change on ecological systems and the importance of studies that link global and regional scale changes to local-scale processes. Such studies can provide

TABLE 2 | Percentage distribution of spring activity per season for the reference (REF) and the future periods (FUT), and for the four spring elevations (Adapted from Levison et al., 2014b).

\begin{tabular}{|c|c|c|c|c|c|c|c|c|}
\hline \multirow[t]{2}{*}{ Spring elevation } & \multicolumn{2}{|c|}{$140 \mathrm{~m}$} & \multicolumn{2}{|c|}{$150 \mathrm{~m}$} & \multicolumn{2}{|c|}{$162 \mathrm{~m}$} & \multicolumn{2}{|c|}{$177 \mathrm{~m}$} \\
\hline & REF & FUT & REF & FUT & REF & FUT & REF & FUT \\
\hline Winter (Dec, Jan, and Feb) & $23.1^{\dagger}$ & $25.1^{\star}$ & 13.8 & $17.5^{\star}$ & 7.9 & $10.8^{*}$ & 7.2 & $12.1^{*}$ \\
\hline Spring (Mar, Apr, and May) & 25.4 & $27.7^{\star}$ & 59.1 & $61.8^{\star}$ & 76.9 & $83.4^{*}$ & 78.4 & $77.8^{*}$ \\
\hline Summer (Jun, Jul, and Aug) & 28.1 & $25.7^{\star}$ & 11.8 & 7.8 & 3.2 & 0.3 & 2.3 & 0.4 \\
\hline Fall (Sep, Oct, and Nov) & 23.4 & 21.4 & 15.2 & 12.9 & 12.0 & 5.5 & 12.2 & 9.7 \\
\hline
\end{tabular}

† All values correspond to ensemble averages.

*The stars correspond to significant differences $(\alpha=0.05)$ according to a Wilcoxon-Mann-Whitney test for paired samples. 
A

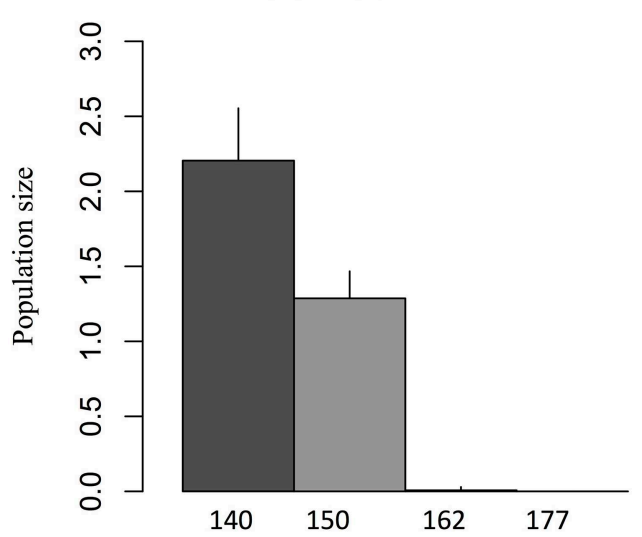

B

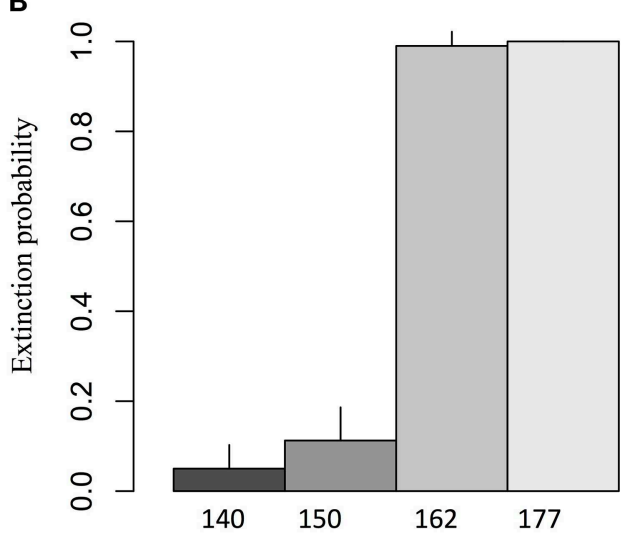

2041-2070
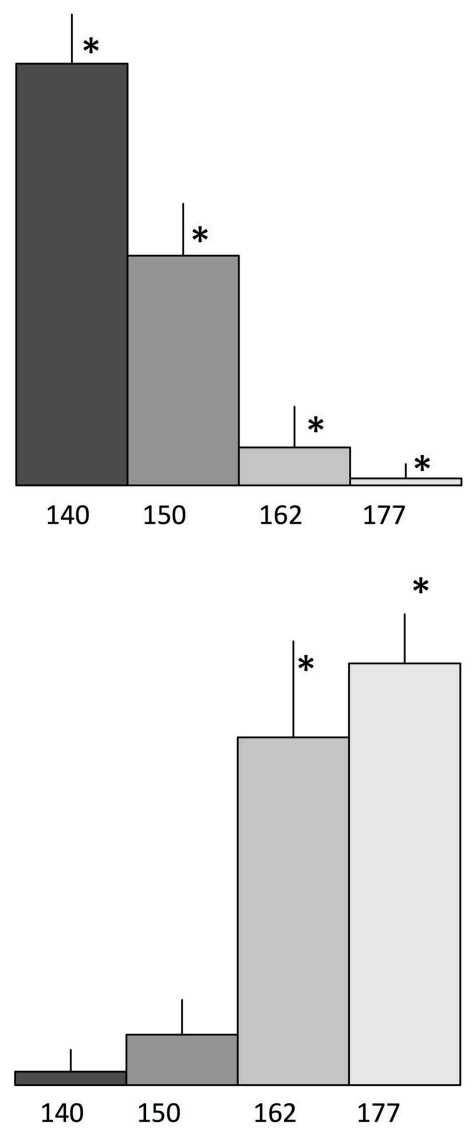

Elevation (m)

FIGURE 5 | (A) Salamander population size and (B) extinction probability observed over a spring of $4 \mathrm{~m}^{2}$ during the reference and future periods, given the projected activity time series for elevations of $140,150,162$, and $177 \mathrm{~m}$. The values correspond to ensemble averages and error bars represent the standard deviation. The stars correspond to significant differences $(\alpha=0.05)$ between the reference climate (1971-2000) and the projected climate (2041-2070) according to a Wilcoxon-Mann-Whitney test for paired samples. valuable insight for conservation initiatives that are typically carried out at this scale.

According to our model, the increased viability of the salamander population may be largely explained by the impacts of climate change on breeding phenology. The effects of global warming on amphibians' breeding have been abundantly documented (Blaustein et al., 2001; Corn, 2005; Li et al., 2013). Indeed, the timing of amphibian reproduction is primarily driven by environmental factors such as temperature and moisture (Carey and Alexander, 2003). As such, their breeding may be directly affected by global warming, resulting in a potentially earlier onset of the reproduction period (Beebee, 1995). The salamander model presented herein is in accordance with this hypothesis. However, while this effect was identified as a positive impact on the Covey Hill salamander population, some authors have suggested that it may rather increase breeder mortality due to early season frosts or floods resulting from snow melt (Corn, 2000, 2005; Inouye et al., 2000). It is acknowledged that the breeding mechanisms included in the salamander model are simplified and that neither frost nor flood-related causes of mortality are modeled. Nevertheless, oviposition is predicted to begin on average 12 days earlier in the future, corresponding approximately to the first week of May. In the context of a warming climate, the adverse effects of snow melt and early frost are rather unlikely in eastern North America at that point in the spring.

Most studies relating amphibian decline to climate change projected an increase of droughts (Araujo et al., 2006; McMenamin et al., 2008). This trend has not been detected for the Covey Hill region. As a result of the predicted increase in precipitation, it is expected that spring activity should intensify. This increase in spring flow is expected to favor salamander reproduction by prolonging the duration of the effective reproduction season. This is a major factor explaining the presence of salamanders at 162 and $177 \mathrm{~m}$ springs in the future. In the recent past (1971-2000), modeled springs were active for less than $2 \%$ of the oviposition period at these elevations, rendering reproduction virtually impossible. The intensification 


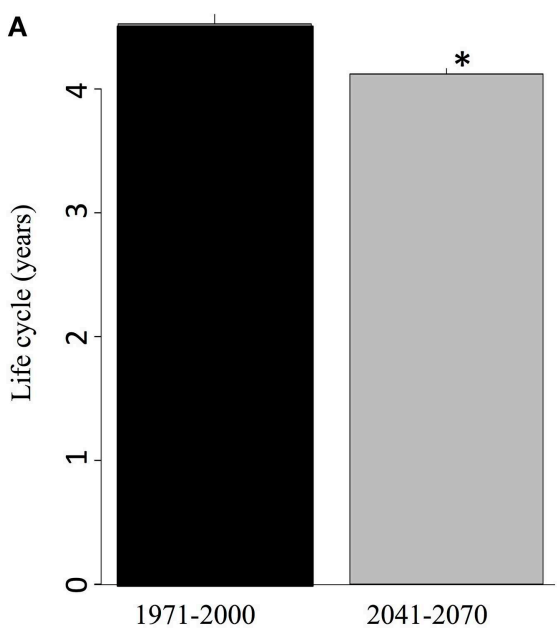

FIGURE 6 | (A) Average number of years for an individual to undergo its entire life cycle (from egg to sexual maturity) for the reference and future periods and (B) length of the breeding season according to the ambient temperature expected for the reference and future
B

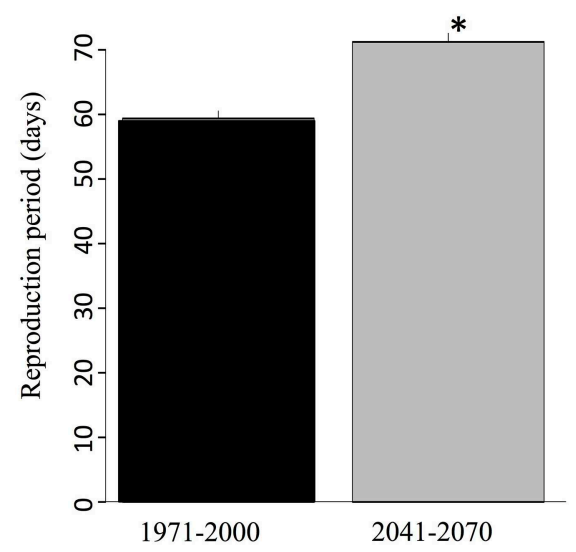

periods. The values correspond to ensemble averages and error bars represent the standard deviation. The stars correspond to significant differences $(\alpha=0.05)$ according to a Wilcoxon-Mann-Whitney test for paired samples. of the hydrological activity during both the effective reproduction season and the reduction of interannual variability may thus serve to create new habitats suited for salamander viability, allowing these species to migrate northwards as the climate changes.

The effects of warmer temperatures on the speed of developmental processes could also be considered as a major benefit for salamander viability on Covey Hill. According to the model proposed here, climate change is expected to substantially accelerate life cycle duration, with a projected reduction of 5 months on average in the future. In nature, the immature stages (eggs, larvae, and juveniles) are by far the most vulnerable (Petranka, 1998). Any acceleration of the development of these phases thus greatly improves the chances of survival to the adult stage (Werner, 1986; Bruce, 2005) and consequently the likelihood that an individual will contribute to reproduction. The increased number of breeders combined with a lengthened reproductive season thus explains the increase of population size projected for the period 2041-2070. Given that Covey Hill lies at the northern limit of the Allegheny Mountain Dusky Salamander's geographical distribution, the projected improvement in conditions for the species with increased temperatures should not be so surprising. The salamander's current range includes much warmer climates to the south of the study area and thus the species should adapt well to a warming environment in the north, especially if it is correlated with an increase of available water.

These predictions must however be considered in the light of the model's limitations. For instance, the individual-based model used in this study ignores all interspecific interactions. Such a restriction is not without consequences. Interspecific competition is recognized as having impacts on the community structure of stream salamanders (Hairston, 1949; Jaeger, 1971; Smith and Pough, 1994), and their occupation of aquatic and terrestrial habitats (Krzysik, 1979). Moreover, spatial segregation or reduction of ecological niches has been observed empirically when stream-dwelling salamander species coexist (Organ, 1961; Krzysik, 1979; Keen, 1982; Grover, 2000). Predation by fish (especially of larvae), snakes, birds, small mammals, and other salamander species, has also been reported several times, thus playing a role in population size regulation (Petranka, 1998). Not only are these dynamics not taken into account by the model, but climate change may potentially alter them in an unknown manner. Furthermore, possible changes to land use on Covey Hill have not been taken into account in the future scenarios. Land use change, including potential increased groundwater withdrawals, may have significant, immediate and prolonged effects on salamander habitat quality. This commends caution: the increased viability of the Allegheny Mountain Dusky Salamander in a context of climate change at Covey Hill may prove to be too optimistic if other anthropocentric pressures are considered.

The positive impacts of climate change predicted for salamander populations on Covey Hill are important for future land conservation efforts, not because they limit the need for habitat protection, but because they reduce uncertainty about probable future conditions - that is to say that according to these results, climate change is not expected to limit the survival of the Allegheny Dusky Salamander on Covey Hill. This conclusion provides a focus for local conservation initiatives to prioritize efforts toward mitigating other identified threats to the species. It also provides support for habitat conservation initiatives for other similar amphibian species at the northern limits of their geographical distributions in the northeastern United States and eastern Canada. The Allegheny Dusky Salamander is likely not an isolated case. The results of these simulations suggest that many amphibious species may be favored by climate change in these regions, becoming abundant where they are currently scarce. 
A

$1971-2000$
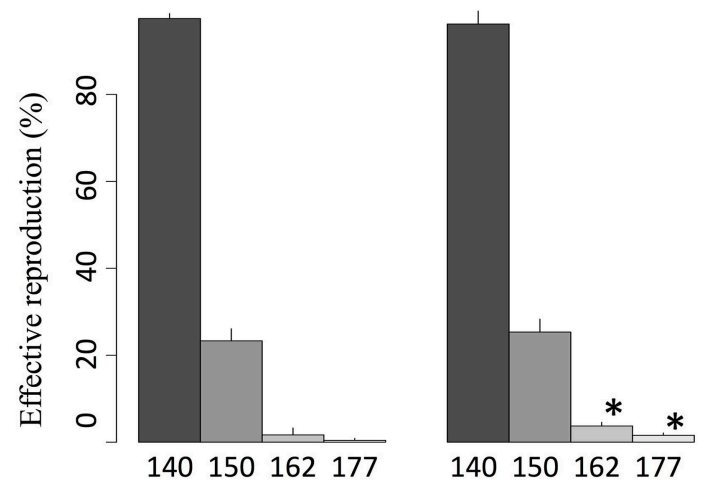

Elevation (m)

B

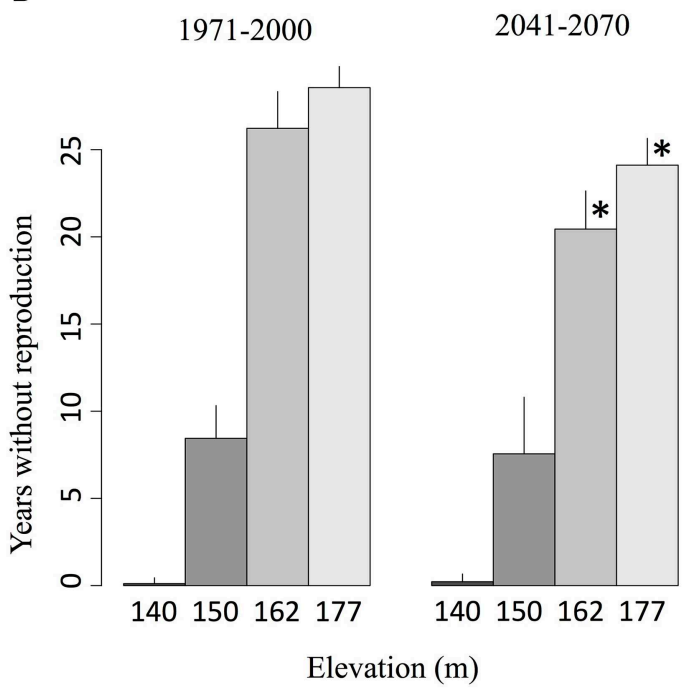

FIGURE 7 | (A) Average proportion of the reproduction season when a spring is active (effective reproduction window) given the projected activity time series for 140, 150, 162, and $177 \mathrm{~m}$ elevations and (B) number of years during which reproduction is impossible due to the inactivity of the spring for each elevation. The values correspond to ensemble averages and error bars represent the standard deviation. The stars correspond to significant differences $(\alpha=0.05)$ between the reference climate (1971-2000) and the projected climate (2041-2070) according to a Wilcoxon-Mann-Whitney test for paired samples.

Local conservation initiatives should thus seek to conserve this habitat so as to increase the chances for survival of these species in the future and to facilitate likely northern migration of the species.

\section{References}

Alvo, R., Bonin, J., and Ostiguy, D. (2003). Rapport sur la Situation de la Salamandre Sombre des Montagnes (Desmognathus ochrophaeus) au Québec. Quebec City, QC: Société de la faune et des parcs du Québec.

Araujo, M. B., Thuiller, W., and Pearson, R. G. (2006). Climate warming and the decline of amphibians and reptiles in Europe. J. Biogeogr. 33, 1712-1728. doi: 10.1111/j.1365-2699.2006.01482.x
It is likely that climate change will not be the only driver of change in the Covey Hill region. Other concomitant anthropogenic pressures, such as intensification of land use or groundwater withdrawal, may act to aggravate or counteract the impacts of climate change on the hydrological regime. Indeed, drainage of springs and redirection of streams for agricultural or domestic uses have been reported repeatedly. This can have significant, immediate and sustained effects on the salamander habitat quality. Caution is obviously a prerequisite when aiming at predicting the local resilience of a species facing multiple scale threats. For this reason, the precautionary principle must prevail. In fact, sound biodiversity conservation strategies are generally not dependent on whether the climate is changing or not and common conservation goals thus remain valid and include: habitat protection, dispersal corridors where habitats are fragmented, management of populations according to their carrying capacity, promotion of genetic, and ecosystem diversity. Strengthening existing land conservation measures (e.g., salamander habitat protection and conservation of preferential infiltration and recharge areas) and developing new initiatives to enhance ecosystem resilience are to be prioritized.

However, even if declining trends have been observed among amphibian populations through field studies (Pounds and Crump, 1994; Lips, 1998; Lips et al., 2006), the results obtained in this current study suggest strongly that generalization can be hazardous. There are no doubts that global warming is likely to have profound impacts on amphibians. However, the longterm effects of climate change on amphibians are difficult to predict. It is generally assumed that climate change is a threat to natural ecosystems, but it is quite possible that some species may prosper in a changed climate in certain locations. The significant population improvement projected for the Allegheny Mountain Dusky Salamanders on Covey Hill for the period 2040-2070 is an example demonstrating that the effects of global warming can be considerably more complex than one may expect, especially when looking at specific locations.

\section{Acknowledgments}

This project was funded by the Consortium Ouranos on regional climatology and adaptation to climate change, as part of the "Fonds vert" for the implementation of the Quebec Government Action Plan 2006-2012 on climate change and its measure (Grant \#554007-107). The authors thank the Nature Conservancy of Canada and the Ministère des Ressources naturelles du Quebec for their support.

Beebee, T. J. C. (1995). Amphibian breeding and climate. Nature 374, 219-220. doi: $10.1038 / 374219 \mathrm{a} 0$

Blaustein, G. A., Belden, L. K., Olson, D. H., Green, D. M., Root, T. L., and Kiesecker, J. M. (2001). Amphibian breeding and climate change. Conserv. Biol. 15, 1804-1809. doi: 10.1046/j.1523-1739.2001.00307.x

Bruce, R. C. (2005). Theory of complex life cycles: application in plethodontid salamanders. Herpetol. Monogr. 19, 180-207. doi: 10.1655/0733-1347(2005)019[0180:TOCLCA]2.0.CO;2 
Carey, C., and Alexander, M. A. (2003). Climate change and amphibian declines: is there a link? Divers. Distrib. 9, 111-121. doi: 10.1046/j.1472-4642.2003.00011.x

Chiew, F. H. S., Teng, J., Vaze, J., and Kirono, D. G. C. (2009). Influence of global climate model selection on runoff impact assessment. J. Hydrol. 379, 172-180. doi: 10.1016/j.jhydrol.2009.10.004

Corn, P. S. (2000). "Amphibian declines: review of some current hypotheses," in Ecotoxicology of Amphibians and Reptiles, eds D. W. Sparling, C. A. Bishop, and G. Linder (Pensacola, FL: Society of Environmental Toxicology and Chemistry), 663-696.

Corn, P. S. (2005). Climate change and amphibians. Anim. Biodivers. Conserv. 28, 59-67. doi: 10.1046/j.1472-4642.2003.00011.x

COSEWIC (2009). Canadian Wildlife Species at Risk. 96. Available online at: http:// www.cosewic.gc.ca/eng/sct0/rpt/rpt_csar_e.cfm.

Croteau, A., Nastev, M., and Lefebvre, R. (2010). Groundwater recharge assessment in the Châteauguay River watershed. Can. Water Resour. J. 35, 451-468. doi: 10.4296/cwrj3504451

D'Amen, M., and Bombi, P. (2009). Global warming and biodiversity: evidence for climate-linked amphibian declines in Italy. Biol. Conserv. 142, 3060-3067. doi: 10.1016/j.biocon.2009.08.004

Enquist, C. A. F. (2002). Predicted regional impacts of climate change on the geographical distribution and diversity of tropical forests in Costa Rica. J. Biogeogr. 29, 519-534. doi: 10.1046/j.1365-2699.2002.00695.x

Girard, P., Parrott, L., Caron, C.-A., and Green, D. M. (2015). Effects of temperature and surface water availability on spatiotemporal dynamics of stream salamanders using pattern-oriented modelling. Ecol. Modell. 296, 12-23. doi: 10.1016/j.ecolmodel.2014.09.026

Globensky, Y. (1986). Géologie de la Région de Saint-Chrysostome et de Lachine (sud). Quebec City, QC: Ministère de l'énergie et des ressources.

Gosling, S. N., Taylor, R. G., Arnell, N. W., and Todd, M. C. (2011). A comparative analysis of projected impacts of climate change on river runoff from global and catchment-scale hydrological models. Hydrol. Earth Syst. Sci. 15, 279-294. doi: 10.5194/hess-15-279-2011

Green, D. M. (2003). The ecology of extinction: population fluctuation and decline in amphibians. Biol. Conserv. 111, 331-343. doi: 10.1016/S00063207(02)00302-6

Green, T. R., Taniguchi, M., Kooi, H., Gurdak, J. J., Allen, D. M., Hiscock, K. M., et al. (2011). Beneath the surface of global change: impacts of climate change on groundwater. J. Hydrol. 405, 532-560. doi: 10.1016/j.jhydrol.2011. 05.002

Grimm, V., and Railsback, S. F. (2005). Individual-Based Modeling and Ecology. New York, NY: Princeton University Press. doi: 10.1515/9781400850624

Grover, M. C. (2000). Determinants of salamander distribution along moisture gradients. Copeia 2000, 156-168. doi: 10.1643/00458511(2000)2000[0156:DOSDAM]2.0.CO;2

Hairston, N. G. (1949). The local distribution and ecology of the Plethodontid salamanders of the southern Appalachian. Ecol. Monogr. 19, 47-73. doi: $10.2307 / 1943584$

Hammerson, G. (2004). “Desmognathus ochrophaeus," in IUCN 2012. IUCN Red List of Threatened Species. Version 2012.2, (Geneva).

Hulme, P. E. (2005). Adapting to climate change: is there scope for ecological management in the face of a global threat? J. Appl. Ecol. 42, 784-794. doi: 10.1111/j.1365-2664.2005.01082.x

Inouye, D. W., Barr, B., Armitage, K. B., and Inouye, B. D. (2000). Climate change is affecting altitudinal migrants and hibernating species. Proc. Natl. Acad. Sci. U.S.A. 97, 1630-1633. doi: 10.1073/pnas.97.4.1630

IPCC (2000). Special report on emissions scenarios (SRES): A Special Report of Working Group III of the Intergovernmental Panel on Climate Change. Cambridge, UK: Cambridge University Press.

Jaeger, R. G. (1971). Competitive exclusion as a factor influencing the distributions of two species of terrestrial salamanders. Ecology 52, 632-637. doi: $10.2307 / 1934151$

Jyrkama, M. I., and Sykes, J. F. (2007). The impact of climate change on spatially varying groundwater recharge in the grand river watershed (Ontario). J. Hydrol. 338, 237-250. doi: 10.1016/j.jhydrol.2007.02.036

Keen, W. H. (1982). Habitat selection and interspecific competition in two species of plethodontid salamanders. Ecology 63, 94-102. doi: 10.2307/1937035

Kosugi, K., Katsura, S., Katsuyama, M., and Mizuyama, T. (2006). Water flow processes in weathered granitic bedrock and their effects on runoff generation in a small headwater catchment. Water Resour. Res. 42:W02414. doi: 10.1029/2005WR004275

Krzysik, A. J. (1979). Resource allocation, coexistence, and the niche structure of a streambank salamander community. Ecol. Monogr. 49, 173-194. doi: $10.2307 / 1942512$

Lannoo, M., ed. (2005). Amphibian Declines: The Conservation Status of United States Species. Berkeley, CA: University of California Press. Available at: http:// books.google.com/books

Larocque, M., Leroux, G., Madramootoo, C., Lapointe, F. J., Pellerin, S., and Bonin, J. (2006). Mise en place d'un Laboratoire naturel sur le mont Covey Hill (Québec, Canada). VertigO 7, 1-11. doi: 10.4000/vertigo.2118

Ledbetter, R., Prudhomme, C., and Arnell, N. (2011). A method for incorporating climate variability in climate change impact assessments: sensitivity of river flows in the Eden catchment to precipitation scenarios. Clim. Change 113, 803-823. doi: 10.1007/s10584-011-0386-0

Levison, J., Larocque, M., Fournier, V., Gagné, S., Pellerin, S., and Ouellet, M. A. (2014a). Dynamics of a headwater system and peatland under current conditions and with climate change. Hydrol. Process. 28, 4808-4822. doi: 10.1002/hyp.9978

Levison, J., Larocque, M., and Ouellet, M. A. (2014b). Modeling low-flow bedrock springs providing ecological habitats with climate change scenarios. j. Hydrol. 515, 16-28. doi: 10.1016/j.jhydrol.2014.04.042

Li, Y., Cohen, J., and Rohr, J. (2013). Review and synthesis of the effects of climate change on amphibians. Integr. Zool. 8, 145-161. doi: 10.1111/1749-4877. 12001

Lips, K. (1998). Decline of a tropical montane amphibian fauna. Conserv. Biol. 12, 106-117. doi: 10.1046/j.1523-1739.1998.96359.x

Lips, K., Brem, F., Brenes, R., Reeve, J. D., Alford, R. A., Voyles, J., et al. (2006). Emerging infectious disease and the loss of biodiversity. Proc. Natl. Acad. Sci. U.S.A. 103, 3165-3170. doi: 10.1073/pnas.0506889103

Mailhot, A., Duchesne, S., Caya, D., and Talbot, G. (2007). Assessment of future change in intensity-duration-frequency (IDF) curves for Southern Quebec using the Canadian Regional Climate Model (CRCM). J. Hydrol. 347, 197-210. doi: 10.1016/j.jhydrol.2007.09.019

Malcolm, J. A., Canran, L., Neilson, R. P., Hansen, L., and Hannah, L. (2006). Global warming and extinctions of endemic species from biodiversity hotspots. Conserv. Biol. 20, 538-548. doi: 10.1111/j.1523-1739.2006.00364.x

McClain, C. R., Stegen, J. C., and Hurlbert, A. H. (2012). Dispersal, environmental niches and oceanic-scale turnover in deep-sea bivalves. Proc. R. Soc. B 279, 1993-2002. doi: 10.1098/rspb.2011.2166

McMenamin, S. K., Hadly, E. A., and Wright, C. K. (2008). Climatic change and wetland desiccation cause amphibian decline in Yellowstone National Park. Proc. Natl. Acad. Sci. U.S.A. 155, 16988-16993. doi: 10.1073/pnas.0809090105

Mearns, L. O., Arritt, R., Biner, S., Bukovsky, M. S., McGinnis, S., Sain, S., et al. (2012). The north american regional climate change assessment program : overview of Phase I results. Bull. Amer. Meteor. Soc. 93, 1337-1362. doi: 10.1175/BAMS-D-11-00223.1

Metcalfe, J. D., Le Quesne, W. J. F., Cheung, W. W. L., and Righton, D. A. (2012). Conservation physiology for applied management of marine fish: an overview with perspectives on the role and value of telemetry. Philos. Trans. R. Soc. Lond. B Biol. Sci. 367, 1746-1756. doi: 10.1098/rstb.2012.0017

Midgley, G. F., Hannah, L., Millar, D., Rutherford, M. C., and Powrie, L. W. (2002). Assessing the vulnerability of species richness to anthropogenic climate change in a biodiversity hotspot. Glob. Ecol. Biogeogr. 11, 445-451. doi: 10.1046/j.1466822X.2002.00307.x

Moberg, A., and Jones, P. D. (2004). Regional climate model simulations of daily maximum and minimum near-surface temperatures across Europe compared with observed station data 1961-1990. Clim. Dyn. 23, 695-715. doi: 10.1007/s00382-004-0464-3

Mpelasoka, F. S., and Chiew, F. H. S. (2009). Influence of rainfall scenario construction methods on runoff projections. J. Hydrometeorol. 10, 1168-1183. doi: 10.1175/2009JHM1045.1

Music, B., and Caya, D. (2007). Evaluation of the hydrological cycle over the mississippi river basin as simulated by the Canadian Regional Climate Model (CRCM). J. Hydrometeorol. 8, 969-988. doi: 10.1175/JHM627.1

Nastev, M., Morin, R., Godin, R., and Rouleau, A. (2008). Developing a conceptual hydrological model for Potsdam sandstones in southwestern Quebec, Canada. Hydrogeol. J. 16, 373-388. doi: 10.1007/s10040-007-0267-9 
Oki, T., and Kanae, S. (2006). Global hydrological cycles and world water resources. Science 313, 1068-1072. doi: 10.1126/science. 1128845

Organ, J. A. (1961). Studies of the local distribution, life history, and population dynamics of the salamander genus Desmognathus in Virginia. Ecol. Monogr. 31, 189-220. doi: 10.2307/1950754

Oudin, L., Hervieu, F., Michel, C., Perrin, C., Andréassian, V., Anctil, F., et al. (2005). Which potential evapotranspiration input for a lumped rainfall-runoff model? J. Hydrol. 303, 290-306. doi: 10.1016/j.jhydrol.2004.08.026

Parrott, L., Chion, C., Gonzales, R., and Latombe, G. (2012). Agents, individuals and networks: modeling methods to inform natural resource management in regional landscapes. Ecol. Soc. 17, 32. doi: 10.5751/es-04936-170332

Petranka, J. W. (1998). Salamanders of the United States and Canada. Washington; London: Smithsonian Institution Press.

Pounds, J. A., and Crump, M. L. (1994). Amphibian declines and climate disturbance: the case of the golden toad and the harlequin frog. Conserv. Biol. 8, 72-85. doi: 10.1046/j.1523-1739.1994.08010072.x

Pounds, J. A., Fogden, M. P. L., Savage, J. M., and Gorman, G. C. (1997). Tests of null models for amphibian declines on a tropical mountain. Conserv. Biol. 11, 1307-1322. doi: 10.1046/j.1523-1739.1997.95485.x

Russell, B. D., Thompson, J.-A. I., Falkenberg, L. J., and Connell, S. D. (2009). Synergistic effects of climate change and local stressors: $\mathrm{CO}_{2}$ and nutrientdriven change in subtidal rocky habitats. Glob. Chang. Biol. 15, 2153-2162. doi: $10.1111 /$ j.1365-2486.2009.01886.x

Samuel, J., Coulibaly, P., and Metcalfe, R. A. (2012). Evaluation of future flow variability in ungauged basins: validation of combined methods. Adv. Water Resour. 35, 121-140. doi: 10.1016/j.advwatres.2011.09.015

Scibek, J., Allen, D. M., Cannon, A. J., and Whitfield, P. H. (2007). Groundwatersurface water interaction under scenarios of climate change using a highresolution transient groundwater model. J. Hydrol. 333, 165-181. doi: 10.1016/j.jhydrol.2006.08.005

Sharbel, T. F., and Bonin, J. (1992). Northernmost record of Desmognathus ochrophaeus: biochemical identification in the Chateauguay River Drainage Basin, Queibec. J. Herpetol. 26, 505-508. doi: 10.2307/1565133
Smith, E. M., and Pough, F. H. (1994). Intergeneric aggression among salamanders. J. Herpetol. 28, 41-45. doi: 10.2307/1564678

Stillman, R. A., and Goss-Custard, J. D. (2010). Individual-based ecology of coastal birds. Biol. Rev. 85, 413-434. doi: 10.1111/j.1469-185X.2009.00106.x

Therrien, R., McClaren, R. G., Sudicky, E. A., and Panday, S. M. (2012). HydroGeoSphere - A Three-dimensional Numerical Model Describing Fullyintegrated Subsurface and Surface Flow and Solute Transport. Waterloo, ON: University of Waterloo.

Thomas, C. D., Cameron, A., Green, R., Bakkenes, M., Beaumont, L. J., Collingham, Y. C., et al. (2004). Extinction risk from climate change. Nature 427, 145-148. doi: 10.1038/nature02121

Turco, M., Sanna, A., Herrera, S., Llasat, M.-C., and Gutiérrez, J. M. (2013). Large biases and inconsistent climate change signals in ENSEMBLES regional projections. Clim. Change 120, 859-869. doi: 10.1007/s10584-013-0844-y

Wake, D. B., and Vredenburg, V. T. (2008). Are we in the midst of the sixth mass extinction? A view from the world of amphibians. Proc. Natl. Acad. Sci. U.S.A. 105, 11466-11473. doi: 10.1073/pnas.0801921105

Werner, E. E. (1986). Amphibian metamorphosis: growth rate, predation risk, and the optimal size at transformation. Am. Nat. 128, 319-341. doi: 10.1086/284565

Wilbanks, T. J., and Kates, R. W. (1999). Global change in local places: how scale matters. Clim. Change 43, 601-628. doi: 10.1023/A:1005418924748

Conflict of Interest Statement: The authors declare that the research was conducted in the absence of any commercial or financial relationships that could be construed as a potential conflict of interest.

Copyright (c) 2015 Girard, Levison, Parrott, Larocque, Ouellet and Green. This is an open-access article distributed under the terms of the Creative Commons Attribution License (CC BY). The use, distribution or reproduction in other forums is permitted, provided the original author(s) or licensor are credited and that the original publication in this journal is cited, in accordance with accepted academic practice. No use, distribution or reproduction is permitted which does not comply with these terms. 